\title{
Scoring method versus TOPSIS method in the evaluation of e-banking services
}

\author{
Witold Chmielarz \\ University of Warsaw, Faculty of Management, \\ in Warsaw \\ ul. Szturmowa 1/3, 02-678 Warsaw, Poland \\ Email: witold@chmielarz.eu
}

\author{
Marek Zborowski \\ University of Warsaw, Faculty of Management, \\ in Warsaw \\ ul. Szturmowa 1/3, 02-678 Warsaw, Poland \\ Email: mzborowski@wz.uw.edu.pl
}

\begin{abstract}
The main objective of this article is to compare of the utility of the multi-criteria TOPSIS method with scoring method and scoring method with preferences. The data was taken from Poland banking sphere in 2017. e-Banking websites were assessed from the point of view of an individual client. eBanking helps to strengthen the bank's position in a competitive market environment; therefore, the high quality of a website frequently plays a decisive role in the perception of a bank as an organization. In the research the authors have used a scoring method, a scoring method with preferences and - in order to verify the correctness of the results and compare them - the TOPSIS method. An additional problem which appeared in the course of the study was the questions of whether the sophisticated multi-criteria methods produce better quality results than simple methods based on a scoring evaluation. Subsequently, on the basis of the obtained findings, the authors have carried out comprehensive and multi-dimensional analyses and presented the conclusions and recommendations drawn on the basis of the aforementioned analyses. The authors' contribution to the research was specifying the criteria for the evaluation of the websites as the main indicators of the perception of the quality of websites, identifying the best e-banking websites and formulating conclusions that may become a starting point for creating an effective quality management systems of e-banking services.
\end{abstract}

\section{INTRODUCTION}

$\mathbf{T}$ HE importance of electronic banking in Poland is evidenced by the constant pace of its development. In relation to the fourth quarter of 2016 the number of individual clients who have potential access to account increased in relation to the fourth quarter of 2017 by over $7 \%$, reaching 35,512 million users ( $92 \%$ of the population), where the number of active individual clients rose by more than $3.5 \%$, reaching the level of 15,889 million (45\% of the population) [9]. It is the fastest growing banking sector - nothing seems to interfere with these positive trends. Over the last ten years, the number of customers has increased by more than 25 million. Thus, it is the sphere, the development of which should be carefully examined and analysed.

The problems related to the functioning of websites, in particular, access to e-banking services, are widely discussed in the literature on the subject, and there is no single formula which would allow their unambiguous assessment and the improvement of their quality. Numerous analyses also do not indicate what effect they have on the development of banking in the countries where they are being examined. There is an ongoing process of searching for the method which would best reflect the tendencies in this sphere and at the same time would be most convenient from the point of view of its users. Literature review shows that bank websites may be analysed from the point of view of their usability (site map, address catalogue) [2], functionality (search, navigation, content) [19], interactivity (accessibility and responsiveness) [14], [18] visualization (colour scheme, background, graphics, text) [7], reliability [1], cost-effectiveness (costs of purchase, transport, the difference in prices in traditional and online shops) [3].

Most of the evaluation methods of e-banking websites are traditional scoring methods based on specific criteria sets, evaluated according to a fixed scale. Among the criteria which are most frequently applied there are technical and functional criteria. Many of them contain factors which may be evaluated in a highly subjective way: text clarity, the attractiveness of the colour scheme, images and photos, the speed of finding specific functions and using them) etc. In addition, some users do not treat particular criteria sets in an equivalent way. On the other hand, there are also numerous problems with determining preferences and relations between them. These problems according to relevant literature on the subject - are solved by multi-criteria methods. However, the question arises whether indeed their more complicated use may in some way be compensated for when compared to the ease and convenience in using simple methods. The authors will attempt to address this question in the article.

\section{DESCRIPTION OF THE RESEARCH METHOD AND THE SAMPLE}

The research in this paper has been conducted using the authors' own criteria sets used for electronic access to accounts of particular banks. The criteria sets were applied since 2006 and they were created on the basis of relevant literature and verified following consultations with the experts. The evaluation criteria were established during an internet discussion conducted with the participation of scientists and researchers representing leading universities dealing with electronic banking in Poland, based on the literature on the subject. At the moment of economic crisis of 2008, a set of anti-crisis criteria, i.e. the selected measures which - in the experts' opinion - were supposed to counteract the potential effects 
of the banking crisis [15] - was added to the set of evaluation criteria used to assess the access to banking services. The second modification took place in 2017 where the authors verified the correctness, comprehensibility and importance of the se-lected criteria for the users with the participation of 244 respondents. Finally, after this verification and consideration of users' comments, the criteria adopted in the studies into the evaluation of banking websites were divided into three main groups: economic criteria, technical, visualisation and security criteria, anti-crisis measures. The respondents evaluated their preferences with regard to criteria groups as well as individual criteria. Specific criteria with preferences calculated as an arithmetic mean of the scores, motivation and justification of their choice are presented in details in [16].

Among the groups, the most important set were economic criteria which obtained on average a $62 \%$ score (including the most important criterion - account maintenance PLN/month (average: checking and savings account) - nearly 8\%), subsequently, technical and security criteria - on average $32 \%$ (the most important security measures $6 \%$ ) as well as anti-crisis measures, on average - $6 \%$.

The presented study constitutes the next stage of the research carried out systematically from 2006 whose primary objective is to evaluate the factors which impact the quality of websites that provide access to individual accounts in banks. Frequently, it is the quality of the website which turns out to be decisive in retaining and acquiring new customers. It is important to notice that the present ranking evaluating the quality of ebanking websites includes also economic factors which are the specific reflection of the current bank policy. In order to evaluate particular criteria in the banks which were selected by the clients, the authors used a standardised, simplified Likert scale [10], in which lack of a particular quality is represented by the value equal to zero, its complete fulfilment is equal to one, average fulfilment of the feature -0.5 and intermediary values such as good fulfilment is equal to 0.75 ; and sufficient fulfilment amounts to 0.25 .

The study has been conducted with the initial application of a simple scoring method and a scoring method with preferences. In the simple scoring method, the authors measure the distance from the maximum value which can be obtained (according to the adopted scale). It concerns the value of the measure of the criterion and in the sense of a distance, it is the same when we measure the distance from the first and second criterion and vice versa. However, the relationship between individual criteria is not determined. Assigning the preference scale, which adds up to the value of $100 \%$, to particular criteria (or criteria groups) can be regarded as such a measure. The normalised linear preference scale determines the participation of particular criteria in the final score. It is important to indicate that scoring methods are seen as subjective evaluation methods, even though their subjectivity appears to be limited together with the number of the interviewed respondents and the application of a preference scale. Despite their drawbacks, these methods are commonly applied and their scores are easy to interpret. The methods which are believed to be more objective, for example, AHP method [11], Promethee II, Electre I and III method, the TOPSIS method and other solutions are rather complex to use and sometimes it is difficult to interpret their findings. The authors' experience, mainly related to the application of AHP method used to evaluate websites, points to the fact that the completion of survey questionnaires is very complicated from the perspective of the respondents participating in the studies. As a result, this may lead to ill-considered and random assessments, and the final scores may frequently be determined by the order of particular criteria. In order to eliminate such prob-lems, the authors have devised their own evaluation method - a conversion method. The data which are used in calculations are collected in the form of the same input tables as in the case of a scoring method. This method combines the simplicity and unambiguity of a scoring method with the precision of relational methods. It consists in establishing the relations of each criterion in relation to other criteria, based on averaged distances from the potential maximum value previously established on the basis of a scoring method.

Based on the above assumptions, in December 2017, the authors have conducted the research into the quality of the ebanking websites of the banks which are most popular among individual clients in Poland. The sample of the study covered 721 respondents. Among them, there were 83 (nearly $12 \%$ of the population) people holding and evaluating two accounts in two different banks, 38 respondents (5\%) having and assessing three accounts in three different banks. In total, the survey participants carried out 1002 evaluations of 28 banking websites. Among the 28 websites, seven responses concerned one bank, none of them was complete and correct, and thus the authors used 21 banks in further analyses. Correct responses were provided by 290 individuals ( $40 \%$ of the respondents), out of which 16 (almost 6\%) people evaluated two websites, and four participants (over 1\%) assessed three of them. In total, there were 334 fully and correctly completed evaluations of banking websites (33\% of all completed survey questionnaires). The participants were 19-50 years old students from randomly selected students groups. More than $98 \%$ of respondents were 18-25 years old, which could have influenced the results of the survey $(15.6 \%$ of the population in Poland are potential clients of e-banking, including over $50 \%$ of active clients in 2016). Among the survey participants, there were $72 \%$ of women and $28 \%$ of men. The majority (55\%) described themselves as working students, $45 \%$ as students. Most people (26\%) stated that their place of birth was a town below 50,000 inhabitants, almost the same number of respondents - cities with more than 500,000 residents, and $23 \%$ - villages.

The greatest number of electronic access accounts was indicated in the case of the clients of mBank (15\%), then iPKO PKO BP S.A. (13\%) and Millenium (12\%). The smallest shares in the examined group were clients holding accounts in: BGŻ Optima and Orange Finance (each approximately $1 \%)$. The spread between the smallest and the largest share of electronic access to accounts in particular banks in the entire sample amounts to $14 \%$. Only in six out of twenty-one banks, 
the participation of clients was above the average amounting to $5 \%$.

\section{COMPARATIVE ANALYSIS OF INTERNET ACCESS TO ACCOUNTS IN ELECTRONIC BANKING WITH THE APPLICATION OF A SCORING METHOD}

In the analysis with the application of a scoring method, the authors used input tables, where each of the clients evaluated bank offers concerning the selected e-banking services and the fees related to using bank accounts which can be managed via the Internet. Next, on the basis of the completed surveys, the authors created one summary table of averaged criteria evaluations generated by the users. On this basis, it was possible to carry out analyses and discuss the obtained findings. There occurred a great discrepancy in the evaluations of the analysed banks. In 2017 it amounted to nearly 13 percentage points (as compared to 2.25 percentage points in 2008), which confirms the thesis that the period of crisis in 2008 increased the radicalism of the evaluations and increased the requirements with regard to tools providing access to account. The best in the ranking were: Orange Finanse $(81.80 \%)$ and Bank Millenium S.A. (80.12\%). The next positions were taken by ING Bank Śląski and Raiffeisen Bank. Interestingly, the first place was taken by a mobile bank which was created on the basis of the cooperation between the most innovative bank, i.e. mBank (taking the fifth position in the ranking) and one of the largest mobile operators, namely, Orange, on the basis of mBank experience. The worst in the ranking were: Bank Pocztowy S.A. and Credit Agricole Polska S.A.. The first thirteen banks in the ranking obtained the scores which were above the average amounting to $76.77 \%$.

In the analysed banks, the transfer to a bank where we hold an account is evaluated as average (over 87\%) and to a different bank (over 84\%). The service of issuing a debit card is evaluated at a slightly lower level (over 83\%), similarly to many different access channels (over 82\%). The exceptionally low interest rates on deposits and relatively highinterest rates on credits in the analysed banks obtained the lowest scores (approximately 64\% of the maxi-mum possible scores). It emerges that the spread between the highest and the lowest scores was relatively high and amounted to nearly 24 percentage points. The scores recorded in the case of the average interest rate of current and savings accounts were alarmingly low and amounted to $67-69 \%$, which undoubtedly does not motivate the users to save money. The discrepancy be-tween the lowest and the highest scores was relatively high and amounted to nearly 24 percentage points. In total, thirteen evaluation criteria were above the average equal to $76.77 \%$, and only ten were below it. It may appear that the respondents generally have a high opinion of the bank websites since all the criteria were rated above the $50 \%$ of the maximum score. However, since websites in Poland strongly compete with each other for many years, the scores should not be seen as satisfactory. The first of the banks in this year's ranking was a new player in the electronic banking market which gained its position owing to banking application for smartphones and tablets. In recent years, however, the highest scores were recorded in the case of the banks holding an established position in traditional internet banking such as ING Bank Śląski S.A., Bank BPH or BZ WBK. Among the first ten positions, there were banks such as Millenium and Getin Bank, as well as the banks which started to implement electronic banking and which have their loyal customers, especially those falling in the middle-age range. The high fourth position was taken by Raiffeisen Bank, which probably resulted from the introduction of numerous modernizations and innovations carried out in recent years and an ongoing advertising campaign.

\section{COMPARATIVE ANALYSIS OF ELECTRONIC ACCESS TO THE ACCOUNT IN E-BANKING WITH THE APPLICATION OF THE SCORING METHOD WITH PREFERENCES}

One of the methods which allow for limiting the specific subjectivity of the experts' and users' evaluations in the scoring method is applying unitary preferences with regard to particular criteria or criteria groups. In the study, the authors divided the criteria into three groups: economic, technical and anti-crisis measures. The fourth group adopted in the study was created according to the preferences of the clients indicated in the research preceding the analyses. In this variant the criteria are as follows: economic criteria are preferred in $62 \%$, technological in $32 \%$ and anti-crisis factors only in $6 \%$. For each of the remaining groups, the authors adopted a variant with a group of dominating criteria: economic criteria $(70 \%$ for economic criteria and $15 \%$ in the case of each of the remaining ones), technological, visualisation and security criteria $(70 \%$ for technological, visualisation and security criteria, $15 \%$ for each the remaining ones), anti-crisis criteria (70\% for anticrisis criteria, and $15 \%$ for each of the remaining ones).

In the first case - of economic preferences - the three leading positions are taken by Orange Finance in the first place, Raiffeisen Bank (which moved from the fourth position), and Nest Bank (which moved from the tenth place). In the technical, visualisation and security variant, the first position is also taken by Orange Finance, mBank moved to the second place, and ING Bank Śląski is next. In the variant connected with the anti-crisis measures the second place is taken by Raiffeisen Bank, and Bank Millenium ranks next. In the last variant - the users' variant - the first place is still occupied by Orange Finance, and subsequent positions are taken by Bank Millenium and Raiffeisen Bank. The results of the rankings with particular types of preferences have significantly changed the order in the ranking and have shown the advantage of particular characteristics in the considered banks.

\section{VERIFICATION OF THE RANKING OF INTERNET ACCESS TO AN E-BANKING ACCOUNT WITH THE APPLICATION OF THE TOPSIS METHOD}

The theoretical assumptions of the TOPSIS method are presented below. In order to evaluate 21 most popular ebanking websites in Poland in 2017 (A1, .., A21), the authors used the set of 20 criteria which were adopted by the users 
$(\mathrm{C} 1, \ldots, \mathrm{C} 20)$

With the use of the MCDA (Multi-Criteria Decision Analysis) selection frameworks provided in [4], [5], [6] the authors chose the TOPSIS method to perform the empirical research. The obtained closeness coefficient $C C_{i}$ is the score value produced by the TOPSIS method and is used to construct the ranking of alternatives (see table 1).

To carry out an analysis based on the TOPSIS method, the authors used the input tables where each of the clients evaluated the bank offers related to selected e-banking services and fees connected with using bank accounts which can be managed via the Internet. Subsequently, on the basis of the completed survey questionnaires, they created one summary table of the averaged criteria evaluations generated by the users. On this basis, the authors were able to carry out relevant analyses and discuss the obtained scores.

In the empirical study, 21 banks (A1 - A21) were evaluated with the use of 20 criteria $(\mathrm{C} 1-\mathrm{C} 20)$. The constructed decision matrix is presented in Table 1 . The preference direction for all the criteria was set to maximum. In the first step of the research, a ranking was created based on the weights obtained with the use of normalized means of all users opinions. The obtained ranking is presented in table 2. The analysis of the ranking allows to observe, that the leading alternative A19 (Raiffeisen Bank Polska SA) obtained approximately four times more score than the worst alternative A4 - Bank Pocztowy SA - (0.6406 compared to 0.1578). On the other hand, the second and third alternative in the rank (A16 - Orange Finance - and A2 - Bank Millennium SA respectively) obtained only slightly less score (0.6337 and 0.6096) than the leading alternative. The average score was 0.4703. Twelve alternatives obtained more than average score and nine alternatives scored worse than average.

Subsequently, the authors studied how the ranking would change if the weights of the criteria were not taken into account. Therefore, in the second step of the research, each criterion obtained an equal score. The produced ranking is presented in table 2. Again, the alternative A19 (Raiffeisen Bank Polska SA) took the first position in the ranking, and the alternative A4 (Bank Pocztowy SA) the last one. However, the alternatives A16 and A2 switched places in the new ranking. The analysis of the table 2 allows to note that as much as 7 alternatives remained unchanged: A19, A17, A7, A20, A6, A9, A4. On the other hand, the alternative A15 (Nest Bank) underwent the most significant change, from position 4 to 9 .

The results of the calculations presented in table 2 show that the use of the TOPSIS method produces basically similar results with regard to the ranking as using the scoring method. This confirms the thesis that if the initial set is not greatly diversified, then the application of the simpler method is comparable to the use of more complex methods (here: the multi-criteria TOPSIS method), and it does not require any additional complicated calculations. The interpretation of the findings is also equally possible and convenient. At least this represents a greater possibility to differentiate the input data in order to examine different hypotheses concerning the distribution of preferences between the criteria of particular groups.

If we compare the scores obtained in the scoring method and the TOPSIS method without the consideration of weight differentiation (carried out with the participation of the research sample), then - as indicated previously, the scores concerning the positions in the ranking are similar, despite the differences in the presentation standard (in the scoring method, the point of reference is the maximum possible level of the quality). Nevertheless, the differences in the rankings are really small. In 21 banks - for equal weights - they occur only in ten cases, and the greatest difference for Raiffeisen Bank amounts to the change of three positions. Fourteen differences (out of 21) occur when comparing the version with preferences. The biggest difference (four places) is recorded in the case of BGŻ Optima. In total, the differences are not as great as those in the case of comparison with the conversion method or the AHP method. In general, apart from the spectacular advancement of Raiffeisen Bank, or the lower position of BGŻ Optima, the differences are on average, the move of one place in the ranking. For equal weights, there is a considerable difference in the spread in the ranking for the TOPSIS method - more than $34 \%$ and simultaneously, twenty percentage points smaller (less than 10\%) for the scoring method. Even greater differences between the high-est and the lowest values are indicated in the case of the version with preferences - for the TOPSIS method amounting to over $34 \%$, for the scoring method to less than $4 \%$.

\section{CONCLUSIONS}

The presented analysis has shown the diversity of the opinions of individual clients on the usability of e-banking websites, in particular, their views concerning the selection and use of websites to meet the daily needs of users related to banking services. At this point, it is important to indicate that the demand is high and greatly diversified. At the end of 2017 in Poland there were 32.6 million of e-banking clients, including 14.7 million of active customers (at least one contact with checking and savings account per month) [12], including 8.9 million of clients using mobile devices to contact the bank (website or application) [13], including 2.2 million users of strictly mobile banking (only via a smartphone application) [8]. Even in 2017, we dealt mainly with the first trend, yet the bank analysts predict that this year the remaining trends will be taking a dominating position.

In this paper, the authors have not differentiated the clients with regards to the devices they use and the tools by means of which they contact their banks. Nevertheless, they evaluated them from the point of view of the device which made it possible to communicate with the bank. The evaluation of the devices allowed drawing the following main conclusions:

- it appears that mobile access to banking services is the most important phenomenon in the electronic banking market. This is evidenced by the position of Orange Finance in this ranking. 
TABLE I

THE DECISION MATRIX - INPUT FOR THE TOPSIS METHOD; SOURCE: THE AUTHORS' OWN WORK

\begin{tabular}{|c|c|c|c|c|c|c|c|c|c|c|c|}
\hline & C1 & C2 & $\mathrm{C3}$ & $\mathrm{C4}$ & C5 & C6 & C7 & C8 & C9 & C10 & C11 \\
\hline A1 & 3.5232 & 4.1151 & 4.4438 & 4.2822 & 4.0845 & 4.1656 & 3.7889 & 3.3620 & 3.2592 & 3.2759 & 3.9667 \\
\hline $\mathrm{A} 2$ & 3.5702 & 4.1488 & 4.5620 & 4.3802 & 4.2314 & 4.3471 & 3.8430 & 3.4876 & 3.4215 & 3.2810 & 4.2231 \\
\hline A3 & 3.1429 & 4.1429 & 4.0000 & 3.9286 & 3.8571 & 4.1429 & 3.4286 & 3.2857 & 2.9286 & 2.8571 & 3.5714 \\
\hline A4 & 3.1739 & 3.5652 & 4.1304 & 3.8261 & 3.5652 & 3.7826 & 3.4348 & 3.1304 & 3.0870 & 3.0870 & 3.4783 \\
\hline A5 & 2.8421 & 3.9474 & 4.4737 & 4.2632 & 4.3158 & 4.2632 & 3.4737 & 2.8947 & 3.0000 & 2.9474 & 3.5263 \\
\hline A6 & 3.3000 & 4.0429 & 4.3286 & 4.0286 & 4.0000 & 3.9143 & 3.6571 & 2.9714 & 3.0000 & 2.9714 & 3.9143 \\
\hline A7 & 3.3684 & 3.9211 & 4.5000 & 4.3684 & 3.9474 & 4.2105 & 3.9737 & 3.1316 & 3.1053 & 3.1842 & 3.9737 \\
\hline A8 & 4.0000 & 4.0000 & 4.4444 & 4.2222 & 3.5556 & & & 3.8889 & 4.0000 & 3.8889 & 3.6667 \\
\hline A9 & 3.2667 & 4.0000 & 4.1667 & 3.8000 & 3.8667 & 4.1000 & 3.7000 & 2.9333 & 3.1667 & 3.0333 & 3.7667 \\
\hline $\mathrm{A} 10$ & 3.4516 & 3.6129 & 3.9677 & 3.7742 & 3.9355 & 4.0968 & 3.6774 & 3.1935 & 3.1290 & 3.1613 & 3.7742 \\
\hline A11 & 3.1818 & 3.6364 & 4.7273 & 4.8182 & 3.9091 & 4.1818 & 3.6364 & 3.5455 & 3.3636 & 3.3636 & 4.0000 \\
\hline A12 & 3.7857 & 4.0714 & 4.3571 & 4.5000 & 4.0000 & 4.3571 & 3.9286 & 3.6429 & 3.1429 & 3.0000 & 3.7857 \\
\hline A13 & 3.5217 & 4.1304 & 4.4239 & 4.2935 & 4.1739 & 4.2500 & 3.7174 & 3.5435 & 3.2174 & 3.2826 & 3.8696 \\
\hline A14 & 3.4805 & 4.1364 & 4.4610 & 4.3312 & 4.0974 & 4.1948 & 3.7792 & 3.3052 & 3.2208 & 3.2987 & 3.7597 \\
\hline A15 & 3.6129 & & & & & & & & & & \\
\hline A16 & 3.8000 & 4.7000 & 4.8000 & 4.6000 & 4.2000 & 4.7000 & 4.3000 & 3.2000 & 2.8000 & 2.9000 & 4.5000 \\
\hline A17 & & & & & & & & & & & \\
\hline A18 & 3.7143 & 4.0000 & 4.1429 & 4.2143 & 3.9286 & 3.9286 & 3.7857 & 3.5000 & 3.1429 & 3.0000 & 3.5000 \\
\hline A19 & 3.8158 & 4.3684 & 4.5000 & 4.2105 & 4.1579 & 4.0526 & 3.8421 & & 3.5000 & & \\
\hline A20 & 3.3043 & 4.0000 & 4.4348 & 4.2609 & 4.0000 & 4.0870 & 3.7826 & 3.4348 & 2.9130 & 2.9565 & 3.4348 \\
\hline $\mathrm{A} 21$ & 3.1818 & 4.1818 & 4.4545 & 4.3636 & 4.0000 & 4.6364 & 4.0909 & 3.5455 & 3.3636 & 3.5455 & 4.0000 \\
\hline & C10 & C11 & $\mathrm{C12}$ & C13 & $\mathrm{C14}$ & C15 & C16 & C17 & C18 & C19 & C20 \\
\hline A1 & 3.2759 & 3.9667 & 3.9993 & 4.3634 & 4.1983 & 4.1147 & 3.9995 & 4.1010 & 4.1614 & 4.3418 & 3.7495 \\
\hline A2 & & & & & & & & & & & \\
\hline A3 & 2.8571 & 3.5714 & 3.7857 & 4.2857 & 4.2143 & 3.7857 & 3.5000 & 3.5714 & 3.7143 & & 3.5000 \\
\hline A4 & 3.0870 & & & & & & & & & & \\
\hline A5 & 2.9474 & 3.5263 & 3.5263 & 4.5263 & 4.3158 & 3.8421 & 3.7368 & 4.0526 & 4.0000 & 4.05 & 3.7368 \\
\hline A6 & & & & & & & & & & & \\
\hline A7 & 3.1842 & 3.9737 & 3.6579 & 4.2105 & 4.0000 & 3.8158 & 3.9474 & 4.0526 & 3.8158 & 3.9737 & 3.6579 \\
\hline A8 & 3.8889 & 3.6667 & 3.6667 & 4.0000 & 4.2222 & 3.6667 & 3.4444 & 3.4444 & 3.6667 & & 4.0000 \\
\hline A9 & 3.0333 & 3.7667 & 3.5333 & 4.1000 & 3.6000 & 3.3000 & 3.5000 & 3.3667 & 3.8333 & 3.7667 & 3.2000 \\
\hline $\mathrm{A} 10$ & 3.1613 & 3.7742 & 3.7742 & 4.0645 & 3.8065 & 3.5806 & 3.7419 & 3.6452 & 3.8065 & 3.6452 & 3.4839 \\
\hline A11 & 3.3636 & 4.0000 & 3.9091 & 4.0000 & 3.9091 & 4.0909 & 4.1818 & 4.0909 & 4.2727 & 4.0909 & 3.9091 \\
\hline A12 & 3.0000 & 3.7857 & 3.7857 & 4.1429 & 4.1429 & 4.0000 & 3.7143 & 3.7143 & 3.7857 & 4.0000 & 3.6429 \\
\hline A13 & 3.2826 & 3.8696 & 4.0217 & 4.3696 & 4.0870 & 4.3152 & 4.1630 & 4.2174 & 4.2391 & & 3.7283 \\
\hline A14 & 3.2987 & 3.7597 & 4.0519 & 4.4221 & 4.1883 & 4.2403 & 4.1623 & 4.2273 & 4.2143 & 4.4416 & 3.7662 \\
\hline A15 & 3.2258 & 4.1935 & 3.3871 & 3.7419 & 3.6452 & 3.6129 & 3.8065 & 4.0323 & 3.9032 & 3.9677 & 3.5806 \\
\hline A16 & 2.9000 & 4.5000 & 3.7000 & 4.2000 & 4.1000 & 4.4000 & 4.6000 & 4.3000 & 4.2000 & 4.3000 & 3.5000 \\
\hline A17 & 3.2481 & 3.9173 & 4.0451 & 4.3459 & 4.2331 & 4.0376 & 3.9023 & 3.9850 & 4.1128 & 4.2782 & 3.8045 \\
\hline A18 & 3.0000 & 3.5000 & 3.5714 & 3.7857 & 3.9286 & 3.4286 & 3.5714 & 3.6429 & 3.7857 & 3.7857 & 3.7857 \\
\hline A19 & 3.6842 & 4.0000 & 3.9737 & 4.1316 & 3.8947 & 4.0526 & 4.0789 & 4.0263 & 4.0000 & 4.0263 & 3.8684 \\
\hline A20 & 2.9565 & 3.4348 & 3.6087 & 3.9130 & 3.9565 & 3.7826 & 3.6957 & 3.7826 & 3.9565 & 4.0000 & 3.3043 \\
\hline A21 & 3.5455 & 4.0000 & 4.0000 & 3.9091 & 4.1818 & 4.1818 & 4.0000 & 4.2727 & 4.0000 & 3.4545 & 3.8182 \\
\hline
\end{tabular}


TABLE II

COMPARISON OF RANKINGS FOR THE 21 BANKS, OBTAINED WITH THE USE OF COMPUTED WEIGHTS AND EQUAL WEIGHTS FOR TOPSIS AND SCORING METHOD AND SCORING METHOD WITH PREFERENCES; SOURCE: THE AUTHORS' OWN WORK

\begin{tabular}{|c|c|c|c|c|c|c|c|c|c|}
\hline & Method & $\begin{array}{r}\text { TOP } \\
\text { Computed }\end{array}$ & $\begin{array}{l}\text { Seights } \\
\text { Ne }\end{array}$ & $\begin{array}{r}\text { TOI } \\
\text { Equal }\end{array}$ & $\begin{array}{l}\text { IS } \\
\text { eights }\end{array}$ & $\begin{array}{r}\text { Scoring method } \\
\text { User W }\end{array}$ & $\begin{array}{l}\text { references } \\
\text { s }\end{array}$ & $\begin{array}{c}\text { Scoring me } \\
\text { Equal Weig }\end{array}$ & \\
\hline & Alternative & TOPSIS & Rank & TOPSIS & Rank & Scoring method & Rank & Scoring method & Rank \\
\hline A1 & Alior Bank SA & $55.54 \%$ & 8 & 0.5795 & 6 & 0.3192 & 8 & $79.30 \%$ & 6 \\
\hline A2 & Bank Millennium SA & $60.96 \%$ & 3 & 0.622 & 2 & 0.3246 & 2 & $80.12 \%$ & 2 \\
\hline A3 & Bank Ochrony Środowiska SA & $33.34 \%$ & 18 & 0.3279 & 19 & 0.2955 & 19 & $73.29 \%$ & 19 \\
\hline A4 & Bank Pocztowy SA & $15.78 \%$ & 21 & 0.1456 & 21 & 0.2812 & 21 & $68.87 \%$ & 21 \\
\hline A5 & Bank Polska Kasa Opieki SA & $37.37 \%$ & 15 & 0.4106 & 14 & 0.3036 & 14 & $75.74 \%$ & 14 \\
\hline A6 & Bank Zachodni WBK SA & $35.81 \%$ & 17 & 0.3597 & 17 & 0.3006 & 17 & $74.36 \%$ & 16 \\
\hline A7 & BGŻ BNP Paribas SA (BNP) & $46.06 \%$ & 13 & 0.4689 & 13 & 0.3111 & 13 & $76.82 \%$ & 13 \\
\hline A8 & BGŻ Optima & $55.71 \%$ & 7 & 0.5279 & 10 & 0.3152 & 11 & $77.00 \%$ & 12 \\
\hline A9 & Credit Agricole Bank Polska SA & $29.05 \%$ & 20 & 0.281 & 20 & 0.2937 & 20 & $72.00 \%$ & 20 \\
\hline A10 & Deutsche Bank Polska SA & $32.42 \%$ & 19 & 0.3367 & 18 & 0.2969 & 18 & $73.32 \%$ & 18 \\
\hline A11 & Euro Bank SA & $50.29 \%$ & 12 & 0.5554 & 8 & 0.3181 & 9 & $78.82 \%$ & 8 \\
\hline A12 & Getin Noble Bank SA & $53.29 \%$ & 10 & 0.5068 & 12 & 0.3153 & 10 & $77.50 \%$ & 11 \\
\hline A13 & ING Bank Śląski SA & $56.24 \%$ & 5 & 0.6023 & 4 & 0.3212 & 5 & $79.91 \%$ & 3 \\
\hline A14 & mBank & $55.02 \%$ & 9 & 0.5905 & 5 & 0.3199 & 7 & $79.78 \%$ & 5 \\
\hline $\mathrm{A} 15$ & Nest Bank & $58.38 \%$ & 4 & 0.5419 & 9 & 0.3203 & 6 & $77.81 \%$ & 10 \\
\hline A16 & Orange Finance & $63.37 \%$ & 2 & 0.62 & 3 & 0.3318 & 1 & $81.80 \%$ & 1 \\
\hline A17 & PKO Bank Polski SA (iPKO) & $50.67 \%$ & 11 & 0.5236 & 11 & 0.3129 & 12 & $77.98 \%$ & 9 \\
\hline A18 & PKO Bank Polski SA (INTELIGO) & $41.78 \%$ & 14 & 0.3768 & 15 & 0.3018 & 16 & $74.14 \%$ & 17 \\
\hline A19 & Raiffeisen Bank Polska SA & $64.06 \%$ & 1 & 0,6375 & 1 & 0.3244 & 3 & $79.82 \%$ & 4 \\
\hline A20 & T-Mobile Usługi Bankowe & $36.74 \%$ & 16 & 0.3721 & 16 & 0.3027 & 15 & $74.61 \%$ & 15 \\
\hline A21 & Volkswagen Bank Polska SA & $55.76 \%$ & 6 & 0.5769 & 7 & 0.3217 & 4 & $79.18 \%$ & 7 \\
\hline
\end{tabular}

- the position of Credit Agricole Bank Polska has significantly decreased in relation to other rankings, and the bank, when compared to previous rankings, lost its position among the top ten banks which obtained the best scores, similarly to T-Mobile Usługi Bankowe,

- the vast majority of active bank clients (62\%) believe that economic criteria, i.e. the first three positions among all the most frequently used services are the most significant criteria in the evaluation of internet access to banking,

- however, more and more people admit that they are inclined to consider the ease of access to mobile banking (nearly $80 \%$ ) and the number of access channels (82\%) when selecting a given website,

- the issues related to anti-crisis measures also fell below the average $(73 \%)$, and it emerges that users slowly start to forget about the crisis of 2008 ,

- the scale of inactive clients (approximately 55\% appears to be alarmingly large in relation to those customers who can potentially use electronic banking. It is true that a few years ago the estimates did not exceed $20 \%$, but the pace of increase in the customer activity in this field is still very slow.

The increasing diversification of banking services necessitates new approaches to the use of tools to assess their suitability and usability for the clients. The calculations obtained in the study carried out with the use of the scoring method and the TOPSIS method create the initial basis for such comparisons. Taking into consideration the basic features of these methods one can conclude that generally the obtained findings are largely similar. Therefore, the general conclusion is that in the case of large sets of homogeneous, uniform data both of these methods seem to be equivalent, and in the analyses it is recommended to use the simplest possible methods because they offer greater possibilities of "manual" analyses. The basic features which are characteristic of both methods are presented in table 3 .

The fact that starting from last year, the long-awaited discrimination between banking services via mobile devices and mobile banking induces the authors to conduct thorough analyses of the "strictly" mobile banking carried out by means of the applications running on smartphones and tablets. The diversity in the sphere of banks operating independently, or in alliances with mobile operators also necessitates the consideration of the justification of making a separate evaluation of e-banking, e-banking used via mobile devices and mobile banking. The problem consists in the fact that clients who use mobile devices are not always fully aware that connecting to a website using a mobile device is not mobile banking. The second problem is that in the course of the previously conducted studies [17], clients claimed that they only engage 
TABLE III

COMPARATIVE CHARACTERISTICS OF THE POSSIBILITIES TO USE THE SCORING METHOD AND THE TOPSIS METHOD; SOURCE: THE AUTHORS' OWN WORK

\begin{tabular}{|l|c|c|}
\hline \multicolumn{1}{|c|}{ Criterion } & Scoring method & TOPSIS method \\
\hline Method & $\begin{array}{c}\text { Simple method with the } \\
\text { possibility to apply user preferences }\end{array}$ & $\begin{array}{c}\text { Multi-criteria method with equal } \\
\text { weights and calculated preferences }\end{array}$ \\
\hline Obtaining input data & Easy & Easy \\
\hline Initial data processing & Easy & Easy \\
\hline Computing method & Easy & Relatively more difficult \\
\hline Interpretation of the findings & Easy & method \\
\hline Criterion & Scoring method TOPSIS & Relatively more difficult \\
\hline Extended analyses & Easy & \\
\hline
\end{tabular}

in low-value transaction when using a smartphone (by means of a website or application), and the remaining operations are carried out by means of personal and desktop computers, frequently not noticing or recording which of these transactions are conducted by means of applications. Thus, this area requires continuous and ongoing research in the field.

\section{REFERENCES}

[1] F. J. Miranda, R. Cortes, C. Barriuso, "Quantitative Evaluation of eBanking Web Sites: an Empirical Study of Spanish Banks", in: The Electronic Journal Information Systems Evaluation, No. 2(9), 2004, pp. 73-82, http://www.ejise.com/issue/download.html?idArticle=766.

[2] H. Bauer, M. Hammerschmidt, T. Falk, "Measuring the Quality of EBanking Portals - an Empirical Investigation", International Journal of Bank, Vol. 23, No. 2, 2005, pp. 153-175; https://papers.ssrn.com/sol3/ papers.cfm?abstract_id $=962227$.

[3] H. W. Webb, L. A. Webb, "SiteQual: an integrated measure of Web site quality", in: Journal of Enterprise Information Management, no. 6 , vol. 17., 2004

[4] J. Wątróbski, "Outline of multicriteria decision-making in green logistics", in: Transportation Research Procedia, 16, 2016, pp. 537-552.

[5] J. Wątróbski, J. Jankowski, "Guideline for MCDA method selection in production man-agement area", in: New frontiers in information and production systems modelling and analysis, Springer, Cham, 2016 pp. 119-138.

[6] J. Wątróbski, J. Jankowski, Z. Piotrowski, "The selection of multicriteria method based on unstructured decision problem description", in: International Conference on Computational Collective Intelligence, Springer, Cham, 2014 pp. 454-465.

[7] M. B. Mateos, A. C. Mera, F. J. Gonzales, O. R. Lopez, "A New Web Assessment Index: Spanish Universities Analysis", Internet Research: Electronic Application and Policy, no. 3, vol. 11., 2001.

[8] mBank, "Grupa mBanku - wprowadzenie, Najbardziej udany wzrost organiczny w Polsce", https://www.mbank.pl/pobierz/msp-korporacje/ wyniki-finansowe/introduction_to_mbank_pol_2015_q3.pdf?noredir.
[9] NetBank, "Bankowość Internetowa i Płatności Bezgotówkowe IV kwartał 2017 r.", https://zbp.pl/public/repozytorium/wydarzenia/images/ marzec_2018/konf/Netbank_Q4_20180329.pdf.

[10] R. Likert, "A Technique for the Measurement of Attitudes:, in: Archives of Psychology, No. 140, 1932.

[11] T. Saaty, "How to Make a decision. The Analytic Hierarchy Process", in: European Journal of Operational Research, Volume 48, Issue 1, 5, 1990, pp. 9-26.

[12] W. Boczoń, "Raport PRNews.pl: Liczba klientów mobile only - IV kw. 2017", https://prnews.pl/ raport-prnews-pl-liczba-klientow-mobile-only-iv-kw-2017-433554.

[13] W. Boczoń,"Raport PRNews.pl: Rynek bankowości mobilnej - IV kw. 2017", https://prnews.pl/ raport-prnews-pl-rynek-bankowosci-mobilnej-iv-kw-2017-433527.

[14] W. C. Chiou, C. C. Lin, C. Perng, "A strategic framework for website evaluation based on a review of the literature from 1995-2006",

Information \& Management, no. 5-6, vol. 47, 2010,
[15] W. Chmielarz, "Methodological Aspects of the Evaluation of Individual E-Banking Services for Selected Banks In Poland", chapt. 11 in: Infonomics for Distributed Business and Decision-Making Environments. Creating Information System Ecology, ed. M. Pańkowska, 2010.

[16] W. Chmielarz, M. Zborowski, "Analysis of e-Banking Websites' Quality with the Appli-cation of the TOPSIS Method - A Practical Study", International Conference on Knowledge-Based and Intelligent Information \& Engineering Systems, 2018, in press.

[17] W. Chmielarz, M. Zborowski, "Comparative Analysis of Electronic Banking Websites in Poland in 2016", in: Information Systems: Research, Development, Applications, Education, eds. S. Wrycza, J. Maślankowski, Lecture Notes in Business Information Processing, 10th SIS-SAND/PLAIS EuroSymposium 2017 Gdańsk, Poland, Springer International Publishing, 2017, pp. 43-56.

[18] Y. K. Migdadi, "Quantitative Evaluation of the Internet Banking Service Encounter's Quality: Comparative Study between Jordan and the UK Retail Banks", in: Journal of Internet Banking and Commerce, no. 2, vol. 13., 2008 .

[19] Z. Yang, S. Cai, Z. Zhou, N. Zhou, "Development and validation of an instrument to measure user perceived service quality of information presenting Web Portals", in: Information \& Management, no. 4, vol. 42, 2005, pp. 234-254. 